\title{
Plasma levels of interleukin-8 and expression of interleukin-8 receptors on circulating neutrophils and monocytes after cardiopulmonary bypass in children
}

\author{
Peter Gessler, MD \\ Juerg Pfenninger, $M D^{b}$ \\ Jean-Pierre Pfammatter, $M D^{b}$ \\ Thierry Carrel, $\mathrm{MD}^{\mathrm{C}}$ \\ Oskar Baenziger ${ }^{\mathrm{a}}$ \\ Clemens Dahinden, MD $^{\mathrm{d}}$
}

\footnotetext{
From the University Children's Hospital, ${ }^{a}$ Zurich, Switzerland; University Children's Hospital, ${ }^{\text {b }}$ Berne, Switzerland; Department of Cardiovascular Surgery, ${ }^{\mathrm{c}}$ University Hospital, Berne, Switzerland; and Institute of Immunology, University of Berne, Berne, Switzerland.

The study was financially supported by a grant from Novartis Stiftung, Basel, Switzerland (No. 99B24). There is no conflict of interest.

Received for publication Oct 8, 2002; revisions requested Nov 25, 2002; revisions received Dec 3, 2002; accepted for publication Jan 10, 2003.

Address for reprints: Peter Gessler, MD, University Children's Hospital, Steinwiesstr. 75, CH 8032, Zurich, Switzerland (E-mail: peter.gessler@kispi.unizh.ch).

J Thorac Cardiovasc Surg 2003;126:718-25

Copyright (๑) 2003 by The American Association for Thoracic Surgery

$0022-5223 / 2003 \$ 30.00+0$

doi:10.1016/S0022-5223(03)00685-8
}

Objective: Cardiopulmonary bypass induces a systemic inflammatory response that causes substantial clinical morbidity. This study sought to determine cellular and humoral variables of inflammation. We hypothesized that chemokines are a major source of stimulation of neutrophils and monocytes in pediatric cardiac surgery.

Methods: We performed an observational prospective clinical study of 20 pediatric patients before and after cardiopulmonary bypass. Plasma levels of interleukin-6, interleukin- 8 , myeloperoxidase, and nitric oxide were measured by immunoassays. Expression of interleukin-8 receptors (CXCR1, CXCR2) and CD14 of circulating neutrophils and monocytes was assessed by flow cytometry. Clinical evaluations included length of inotropic support and mechanical ventilation as well as oxygenation.

Results: Two hours after cardiopulmonary bypass, plasma levels of interleukin-6 and interleukin- 8 were strongly increased $(P=.0001$ and $P=.0032$, respectively). Interleukin- 6 and interleukin- 8 concentrations correlated with the length of inotropic support, as well as with the length of mechanical ventilation ( $\mathrm{r}>.70, P \leq .0006)$, and were inversely related to the ratio of arterial oxygen tension to fraction of inspired oxygen. There was a strong association between the postoperative levels of interleukin- 6 and nitric oxide, as well as between interleukin- 6 and CD14 expression on monocytes $(\mathrm{r}>.62, P \leq .0031)$. The expression of CXCR2 but not CXCR1 on neutrophils and monocytes correlated negatively with the levels of interleukin-8 and myeloperoxidase.

Conclusions: After cardiopulmonary bypass, impairment of cardiovascular and respiratory function correlated with the levels of interleukin- 6 and interleukin- 8 as mediators of an inflammatory response. The negative correlation of CXCR2 expression with interleukin-8 and myeloperoxidase indicates that myeloid cells were stimulated by CXC chemokines with Glu-Leu-Arg (ELR) motif and thereby contributed to tissue damage, leading to impairment of cardiovascular and respiratory function.

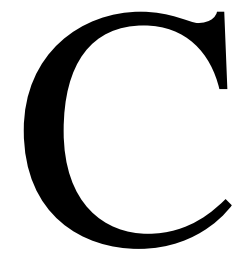
ardiac surgery with cardiopulmonary bypass (CPB) leads to an acute inflammatory response associated with activation of complement and release of cytokines and chemokines into the circulation, as well as activation of inflammatory cells. ${ }^{1,2}$ Elevated levels of proinflammatory cytokines such as tumor necrosis factor (TNF)- $\alpha$, interleukin (IL)-6, and IL-8 have been reported. ${ }^{3,4}$ This inflammatory response is counterbalanced by a complex system of inhibitors such as IL-10 
TABLE 1. Patient demographic data and clinical characteristics

\begin{tabular}{|c|c|c|c|c|c|c|c|c|c|}
\hline No. & Diagnosis & $\begin{array}{c}\text { Age } \\
\text { (months) }\end{array}$ & $\begin{array}{l}\text { Weight } \\
\text { (kg) }\end{array}$ & $\begin{array}{l}\text { CPB } \\
(\min )\end{array}$ & $\begin{array}{c}\text { Aortic crossclamp } \\
\text { time (min) }\end{array}$ & $\begin{array}{l}\text { Inotropic support } \\
\text { (hours) }\end{array}$ & $\begin{array}{l}\text { Inotropic drugs } \\
\text { used } \leq 24 \text { hours* }\end{array}$ & $\begin{array}{c}\text { Mechanical } \\
\text { ventilation (hours) }\end{array}$ & $\begin{array}{l}\mathrm{PaO}_{2} / \mathrm{FIO}_{2} \\
(\mathrm{~mm} \mathrm{Hg})\end{array}$ \\
\hline 1 & Aortic stenosis & 78 & 17.5 & 29 & 19 & 0 & & 8 & 673 \\
\hline 2 & VSD & 4 & 3.9 & 81 & 29 & 70 & $\mathrm{Dn}$ & 81 & 134 \\
\hline 3 & ASD & 69 & 16.0 & 36 & 9 & 0 & & 12 & 436 \\
\hline 4 & VSD & 109 & 38.0 & 49 & 24 & 0 & & 5 & 444 \\
\hline 5 & $A-V$ canal & 5 & 4.2 & 109 & 56 & 69 & Do, Ep, No & 98 & 70 \\
\hline 6 & Fallot tetralogy & 18 & 10.5 & 62 & 36 & 26 & Do, Dn & 27 & 206 \\
\hline 7 & DORV & 148 & 39.7 & 75 & 41 & 40 & Dn & 28 & 527 \\
\hline 8 & Cor triatriatum & 19 & 9.5 & 105 & 27 & 96 & Do, Dn, No & 120 & 140 \\
\hline 9 & VSD & 8 & 6.9 & 84 & 41 & 46 & $\mathrm{Dn}, \mathrm{Ep}$ & 25 & 354 \\
\hline 10 & DORV & 13 & 7.9 & 102 & 49 & 30 & Dn, Ep & 25 & 309 \\
\hline 11 & A-V canal & 5 & 5.6 & 104 & 51 & 56 & Dn & 45 & 249 \\
\hline 12 & ASD & 92 & 28.4 & 34 & 23 & 0 & & 4 & 440 \\
\hline 13 & $A-V$ canal & 46 & 21.0 & 47 & 27 & 20 & $\mathrm{Dn}$ & 19 & 392 \\
\hline 14 & Fallot tetralogy & 69 & 20.8 & 81 & 36 & 21 & $\mathrm{Dn}$ & 18 & 390 \\
\hline 15 & VSD & 162 & 51.8 & 48 & 27 & 23 & Dn & 9 & 455 \\
\hline 16 & $A-V$ canal & 5 & 5.6 & 80 & 42 & 73 & Dn, Ep, No & 71 & 432 \\
\hline 17 & Fallot tetralogy & 8 & 8.1 & 96 & 50 & 24 & Dn & 42 & 348 \\
\hline 18 & VSD & 9 & 7.3 & 49 & 25 & 23 & Dn & 6 & 390 \\
\hline 19 & ASD & 138 & 42.6 & 35 & 15 & 11 & Dn & 4 & 410 \\
\hline 20 & A-V canal & 4 & 4.5 & 137 & 66 & 96 & Dn, Ep & 120 & 266 \\
\hline
\end{tabular}

and soluble cytokine receptors. ${ }^{5-7}$ Proinflammatory cytokines can induce the release of nitric oxide (NO) by endothelial cells, smooth muscle cells, and inflammatory cells through the inducible form of the enzyme NO synthase. ${ }^{8-10}$ NO is implicated in the pathophysiology of the inflammatory state and induces vasodilation, increased vascular permeability, and inhibition of myocardial contractility. ${ }^{11}$ In addition, NO has a protective role by inhibiting neutrophilendothelial cell adhesion or by blocking neutrophil accumulation in the inflammatory sites. ${ }^{12,13}$ Because inflammatory cells release a variety of proteases and oxidants as final mediators of tissue damage, ${ }^{14,15}$ reduced infiltration of the myocardium by inflammatory cells may reduce tissue injury. ${ }^{9}$ The process of attraction and activation of leukocytes to tissues during an inflammatory process is controlled by chemokines. ${ }^{16}$ IL-8 and other CXC chemokines (named according to the position of the first 2 cysteines separated by 1 amino acid) are potent neutrophil chemotactic and activating peptides, which are proposed to be major mediators of inflammation. ${ }^{17}$ IL-8 is produced by a variety of cell types including monocytes, $\mathrm{T}$ lymphocytes, neutrophils, fibroblasts, endothelial cells, and epithelial cells. The central role of CXC chemokines in neutrophil accumulation at sites of inflammation has been demonstrated in animal models of myocardial ischemia. ${ }^{18,19}$ Two IL-8 receptor types (CXCR1 and CXCR2) have been described on human neutrophils; both have high affinity for IL-8 but CXCR2 has additional affinity to other $\mathrm{CXC}$ chemokines containing a common amino-terminal Glu-Leu-Arg (ELR) amino acid sequence. ${ }^{20-22}$

The proinflammatory events after $\mathrm{CPB}$ manifest clinically as capillary leak syndrome with generalized edema, low cardiac output, and multiple organ dysfunction. ${ }^{23,24}$ Monocytes and neutrophil granulocytes may undergo activation, releasing proteinases and oxidants as well as inflammatory cytokines, which may influence cardiovascular and respiratory function. The role of chemokines as a possible source of cellular activation was assessed.

\section{Methods}

\section{Patients and Blood Sampling Protocol}

The study was approved by the local ethics committee. Informed written consent from the parents of each child was obtained. The studied population included 20 consecutive patients. All patients were operated by the same 2 surgeons. Patient demographic data and clinical characteristics are shown in Table 1.

Patients were ventilated (Draeger Evita IV, Luebeck, Germany) using biphasic positive airway pressure mode. $\mathrm{FIO}_{2}$ was adjusted to maintain a $\mathrm{PaO}_{2}$ level of $10 \mathrm{kPa}$ or greater. Ratio of arterial oxygen tension to fraction of inspired oxygen $\left(\mathrm{PaO}_{2} / \mathrm{FIO}_{2}\right)$ was calculated 2 hours after CPB. Respiratory function was determined as the duration of mechanical ventilation and the ratio of $\mathrm{PaO}_{2} / \mathrm{FIO}_{2}$ (in all cases, repair of cardiac lesion resulted in complete separation of pulmonary and systemic circulations). Mechanical ventilation was discontinued according to a standard weaning protocol, which is followed for all patients before extubation. 
Cardiovascular function was assessed by the length of inotropic support after $\mathrm{CPB}$ and the number of inotropic drugs used during the first 24 hours after CPB. Postoperative inotropic support was done according to age-adapted reference values for blood pressure and clinical variables (ie, skin perfusion, urine output) using dopamine, dobutamine, epinephrine, or norepinephrine, either as a single drug or in combination. Prescription of the drugs was done by a team of senior pediatric intensivists following written internal guidelines. The intensivists were unaware of the laboratory results done for research purpose.

Arterial blood samples for immunophenotyping of cells as well as for cytokine assays were collected from each patient before and 2 hours after $\mathrm{CPB}$. Measurements of cell receptors were done immediately after sample collection. Blood samples for cytokine assays were immediately centrifuged and the plasma stored at $-70^{\circ} \mathrm{C}$.

\section{CPB Management}

The extracorporeal circuit (ECC) consisted of a roller pump, cardiotomy reservoir, tubing set, and oxygenator. The circuit was primed with a mixture of red blood cell concentrate, human albumin, sodium bicarbonate $8.4 \%$, mannitol $20 \%$, magnesium chloride, aprotinin (Bayer, Leverkusen, Germany), and heparin (Roche Pharma, Grenzach, Switzerland). It should be pointed out that aprotinin was used in all patients and the dosage was consistent in all patients. Cardioplegia solutions were the standard Buckberg potassium-based solutions (pharmacy of the Inselspital, Berne) mixed with blood in a ratio of $4: 1$ (blood:cardioplegia). The cardioplegia protocol included cold antegrade induction $(30 \mathrm{~mL}$ per $\mathrm{kg}$ of body weight for 5 minutes) and maintenance. For reperfusion, a warm solution enriched with aspartate/glutamate was given $(30 \mathrm{~mL}$ per $\mathrm{kg}$ of body weight over a period of 2 minutes, concentration of aspartate and glutamate $13 \mathrm{mmol} / \mathrm{L}$, respectively). The ECC flow rates were between $2.4 \mathrm{~L} / \mathrm{min} / \mathrm{m}^{2}$ and $2.8 \mathrm{~L} / \mathrm{min} / \mathrm{m}^{2}$. Ultrafiltration was performed in all patients in a standardized manner during the rewarming period using a blood concentrator $(20 \mathrm{~mL}$ per minute resulting in a volume of $600 \pm$ $200 \mathrm{~mL})$. Hypothermia $\left(32^{\circ} \mathrm{C}\right)$ was maintained during surgery. The injected heparin was neutralized with protaminhydrochloride (ICN Pharmaceuticals, Frankfurt, Germany) after CPB. The aorta was clamped for $34.7 \pm 14.7$ minutes (mean $\pm \mathrm{SD}$ ); CPB lasted 72.2 \pm 30.7 minutes (mean $\pm \mathrm{SD})$ (Table 1$)$.

\section{Immunophenotyping of Cells}

Cell surface receptors were detected using a standard technique for immunophenotyping. Arterial blood anticoagulated with ethylenediaminetetraacetic acid was used and measurements were done immediately after sample collection. Fluorescent monoclonal antibodies (mAb): fluorescein isothiocyanate-conjugated mouse antihuman CD14 (Clone M5E2), anti-CDw128 (IL-8RA/CXCR1, Clone 5A12)-phycoerythrin (PE) mAb, and anti-IL-8RB (CXCR2, Clone 6C6)-PE mAB (Pharmingen, Heidelberg, Germany), isotype-matched controls (Becton Dickinson, Heidelberg, Germany). Fixation of leukocytes and lysis of erythrocytes were done with fluorescence-activated cell sorter (FACS)-lysing solution (Becton Dickinson). For estimation of the number of $\mathrm{mAb}-\mathrm{PE}$ bound per cell, beads conjugated with known levels of PE were used (QuantiBRITE PE, Becton Dickinson). A total of 10,000 cells were acquired per measurement using a FACSCalibur flow cytometer (Becton Dickinson). A 2-parameter light scatter dot plot was created and a software gate was set around the monocytes and neutrophil granulocytes using the CellQuest software (Becton Dickinson). The gated cells were analyzed for their fluorescence properties, and results are expressed as relative fluorescence intensity (RFI). RFI values are directly proportional to the respective expression of receptors on cell surface.

\section{Plasma Levels of IL-6, IL-8, Myeloperoxidase, and Total NO}

Concentrations of IL- 6 and IL- 8 were measured using a particlebased immunoassay with fluorescent detection by flow cytometry (Cytometric Bead Array, human inflammation kit, Becton Dickinson) according to the manufacturer's instructions. Assay sensitivity for IL-6 was $2.5 \mathrm{pg} / \mathrm{mL}$ and for IL-8, $3.6 \mathrm{pg} / \mathrm{mL}$. The range defining the minimum and maximum quantifiable level was 10 to $5000 \mathrm{pg} / \mathrm{mL}$, respectively.

\section{Plasma Nitrate and Nitrate}

Myeloperoxidase (MPO) in plasma was measured with a commercial enzyme-linked immunosorbent assay kit (R\&D Systems, Abingdon, UK). Sensitivity and dynamic range for MPO was 1.5 $\mathrm{ng} / \mathrm{mL}$, with a range of 1.5 to $100 \mathrm{ng} / \mathrm{mL}$.

Plasma samples were ultrafiltered through a 10,000 molecular weight cutoff filter to eliminate proteins (Microcon7; Millipore, Bedford, Mass). As most of the $\mathrm{NO}$ is oxidized to nitrite $\left(\mathrm{NO}_{2}{ }^{-}\right)$ and nitrate $\left(\mathrm{NO}_{3}{ }^{-}\right)$, the concentrations of these anions are used as a quantitative measure of $\mathrm{NO}$ production. After the conversion of $\mathrm{NO}_{3}{ }^{-}$to $\mathrm{NO}_{2}{ }^{-}$, the spectrophotometric measurement is accomplished by using the Griess reaction (Total Nitric Oxide Assay, R\&D systems). Sensitivity and range was $<1.35 \mu \mathrm{mol} / \mathrm{L}$ with a range of 3.12 to $100 \mu \mathrm{mol} / \mathrm{L}$.

\section{Statistical Analysis}

Statistical analysis was performed by paired Wilcoxon test. Correlation trends were assessed by using Spearman rank correlation coefficient $r$. Data are presented as means \pm SD unless otherwise noted.

\section{Results}

\section{IL-6 and IL-8 Concentrations}

Two hours after CPB, plasma levels of IL-6 and IL-8 were both strongly increased compared with preoperative values (IL-6 postoperative levels $384.4 \pm 300.7 \mathrm{pg} / \mathrm{mL}$ versus preoperative levels $34.2 \pm 37.0 \mathrm{pg} / \mathrm{mL}, P=.00004$, and IL-8 levels $111.0 \pm 99.2 \mathrm{pg} / \mathrm{mL}$ versus $21.3 \pm 18.0 \mathrm{pg} / \mathrm{mL}$, $P=.0003$, respectively). There was a statistically significant correlation between postoperative levels of IL-6 and IL-8 ( $\mathrm{r}=0.5951, P=.0057)$. Plasma concentrations of both IL- 6 and IL- 8 determined 2 hours after CPB were correlated to the duration of $\mathrm{CPB}$ and to aortic clamp time (IL-6 to CPB time $\mathrm{r}=0.7424, P=.0002$, and to aortic clamp time $\mathrm{r}=0.5774, P=.0077$; IL-8 to $\mathrm{CPB} \mathrm{r}=0.6925$, $P=.0007$, and to aortic clamp time $\mathrm{r}=0.6269, P=.0031$, respectively). Increased levels of IL-6 and IL-8 determined 


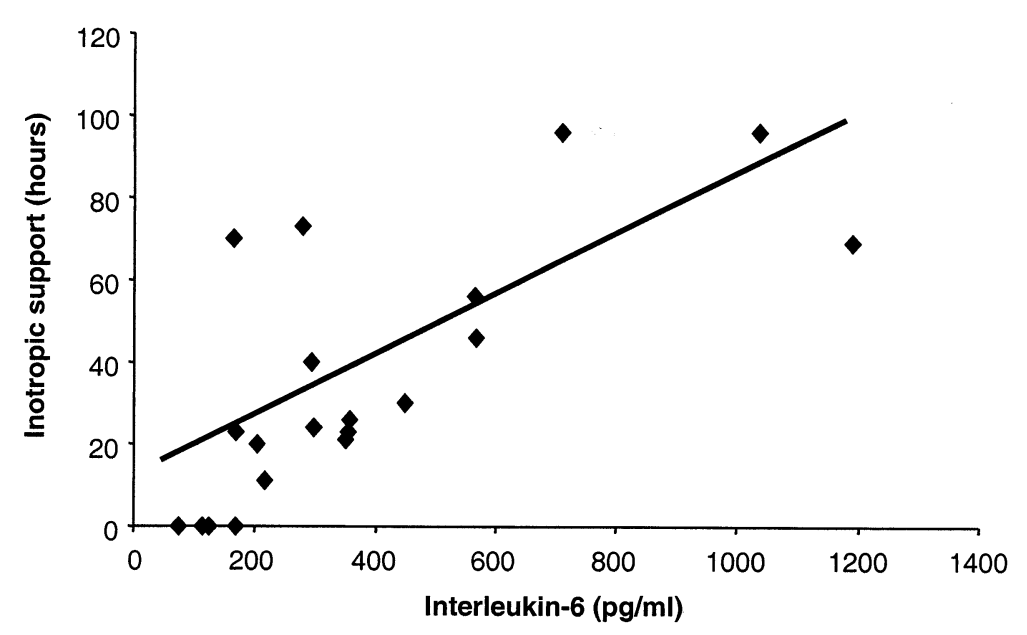

Figure 1. Correlation between plasma interleukin-6 concentrations $(\mathrm{pg} / \mathrm{mL})$ determined 2 hours after cardiopulmonary bypass to the length of inotropic support (hours) $(r=0.7263, P=.0003)$.

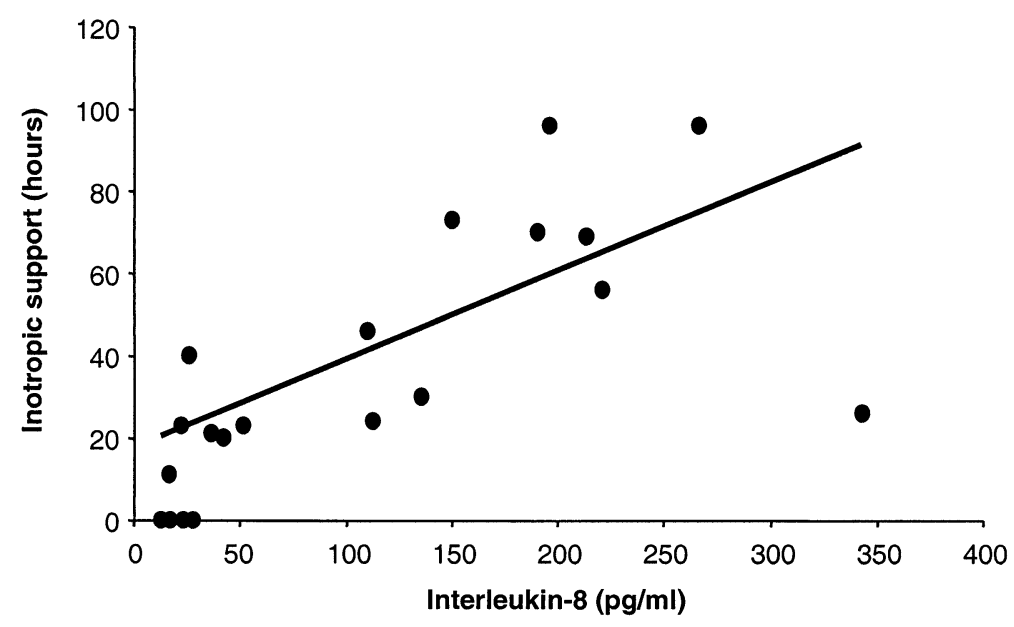

Figure 2. Correlation between plasma interleukin-8 concentrations $(\mathrm{pg} / \mathrm{mL})$ determined 2 hours after cardiopulmonary bypass to the length of inotropic support (hours) $(r=0.7000, P=.0006)$.

2 hours after CPB were associated with increased duration of inotropic support $(\mathrm{r}=0.7263, P=.0003$, and $\mathrm{r}=$ $0.7001, P=.0006$, respectively) (Figures 1 and 2), as well as with prolonged need for mechanical ventilation $(\mathrm{r}=$ $0.7456, P=.0002$, and $\mathrm{r}=0.7025, P=.0006)$ and decreased $\mathrm{PaO}_{2} / \mathrm{FIO}_{2}$ after CPB $(\mathrm{r}=-0.6989, P=.0005$, and $\mathrm{r}=-0.7676, P=.0002$, respectively) (Figures 3 and 4).

\section{Plasma Levels of MPO and Total NO}

MPO is a specific marker of primary neutrophil granules, which are released in response to strong activating stimuli. Postoperative MPO levels were elevated in all patients compared with preoperative values $(13.7 \pm 6.5 \mathrm{ng} / \mathrm{mL}$ versus $2.9 \pm 1.6$ before $\mathrm{CPB}, P=.0001)$. There was a correlation between postoperative levels of MPO and IL-8 ( $\mathrm{r}=0.4467, P=.0481)$, but no correlation was found between MPO and IL-6 $(\mathrm{r}=0.1661, P=.4843)$. In contrast, postoperative levels of IL-6 and IL- 8 were both strongly correlated to the levels of total NO $(\mathrm{r}=0.6295, P$ $=.0030$ and $\mathrm{r}=0.6166, P=.0038$, respectively).

\section{CD14 Expression on Monocytes}

After CPB, expression of CD14 on the surface of monocytes correlated with increased levels of IL-6 ( $\mathrm{r}=0.6267, P=$ $.0031)$ as well as with the plasma levels of total NO $(\mathrm{r}=$ $0.4443, P=.0496$ ). In contrast, preoperatively neither IL-6 levels nor NO levels correlated with the expression of CD14 $(\mathrm{r}=-0.4440, P=.0514$, and $\mathrm{r}=0.3786, P=.1100$, respectively). 


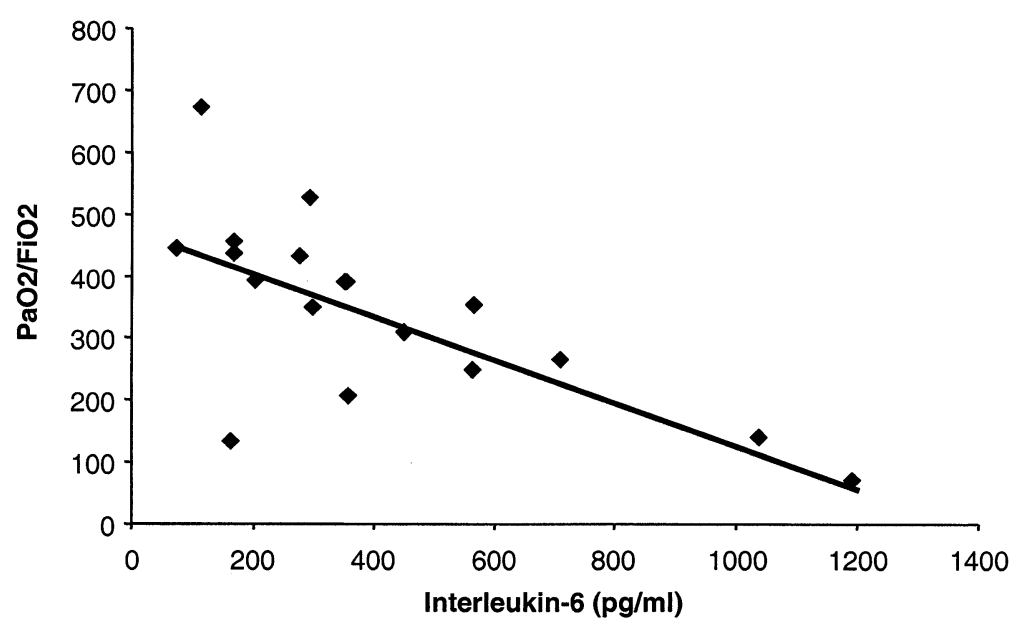

Figure 3. Postoperative plasma levels of interleukin-6 (pg/mL) in relation to the ratio of $\mathrm{PaO}_{2} / \mathrm{FiO}_{2}$ at 2 hours after cardiopulmonary bypass $(r=-0.6989, P=.0005)$.

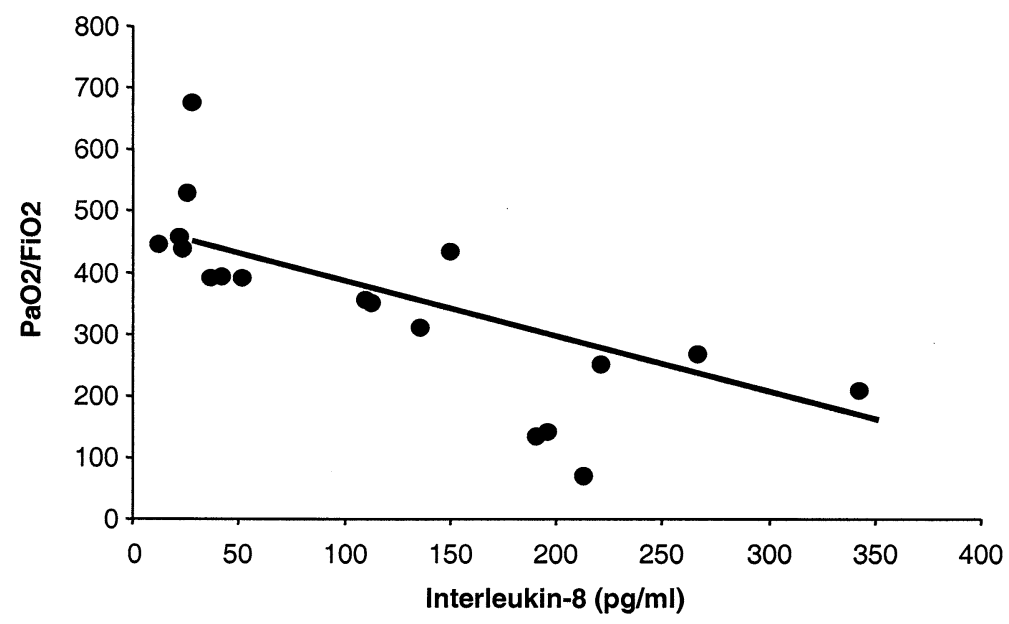

Figure 4. Postoperative plasma levels of interleukin-8 $(\mathrm{pg} / \mathrm{mL})$ in relation to the ratio of $\mathrm{PaO}_{2} / \mathrm{FiO}_{2}$ at 2 hours after cardiopulmonary bypass $(r=-0.7676, P=.0002)$.

CXCR1, CXCR2 on Neutrophils and Monocytes

Analysis of CXCR1 and CXCR2 using mAbs specific for the 2 IL-8 receptor subtypes showed that the expression of CXCR2, but not CXCR1, on neutrophils and monocytes was negatively correlated with the plasma levels of IL-8 (neutrophil CXCR2 to IL-8 correlation $\mathrm{r}=-0.6724, P=$ .0012 , and monocyte CXCR2 correlation to IL-8 $\mathrm{r}=$ $-0.5454, P=.0125)$. Furthermore, decreased expression of CXCR2 on neutrophils and monocytes was associated with increased levels of MPO ( $\mathrm{r}=-0.4609, P=.0408$, and $\mathrm{r}=$ $-0.6853, P=.0009$, respectively) (Figure 5). Again, expression of CXCR1, either on neutrophils or on monocytes, did not correlate to the plasma levels of MPO.

\section{Discussion}

After CPB, elevated levels of the proinflammatory cytokines IL-6 and IL-8 were associated with impaired respiratory and cardiovascular function. Increased levels of $\mathrm{NO}$ and MPO correlated with monocyte and neutrophil activation, possibly due to chemokine stimulation via CXCR2.

Increased levels of IL- 6 determined 2 hours after CPB were associated with increased concentrations of $\mathrm{NO}$ and were followed by a prolonged need for inotropic medication. The suppression of the cardiovascular system can be attributed to a direct inhibitory effect of IL-6 on myocardial contractility. ${ }^{11}$ Most nucleated cells have been shown to express and synthesize IL- 6 . The most prominent source 


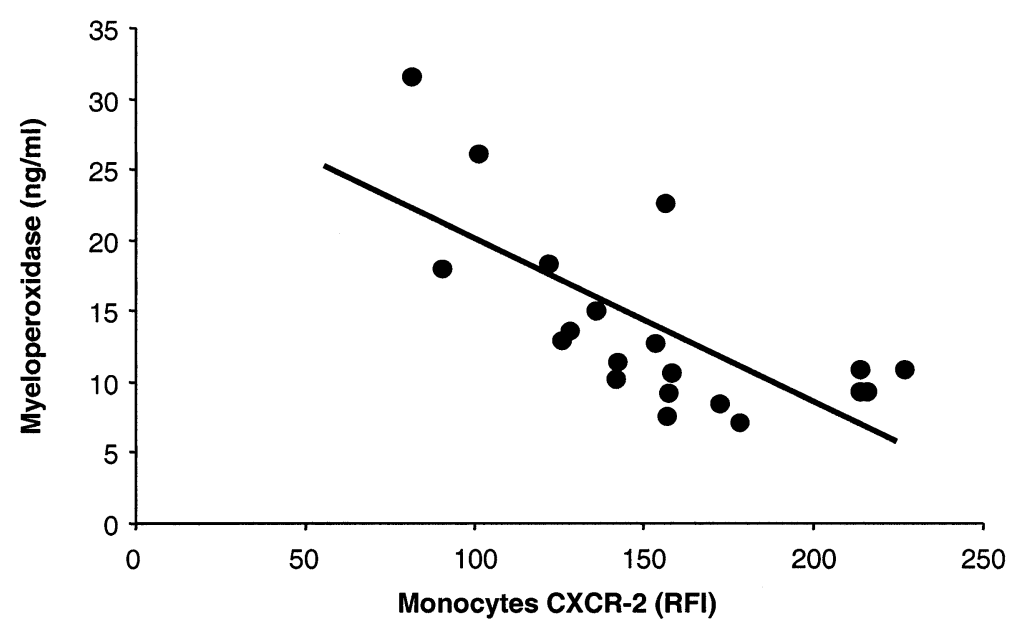

Figure 5. Postoperative plasma levels of myeloperoxidase $(\mathrm{ng} / \mathrm{mL})$ in relation to the expression of CXCR-2 on monocytes ( $r=-0.6853, P=.0009$ ). $R F I$, Relative fluorescence intensity.

appears to be stimulated monocyte-macrophages and cytokine-stimulated stromal cells-fibroblasts and epithelial cells, as well as endothelial cells. ${ }^{25}$ More specifically, increased expression of IL-6 was demonstrated in myocytes and interstitial fibroblasts in the failing myocardium. ${ }^{26,27}$ One possibility of stimulating monocyte-macrophages is mediation through binding of lipopolysaccharide to the leukocyte receptor $\mathrm{CD} 14 .{ }^{28,29} \mathrm{CD} 14$ has been shown to mediate responses to many pathogen-derived ligands and is one of many receptors involved in the recognition and clearance of apoptotic cells. ${ }^{30-32}$ Cellular activation via CD14 results in the production of inflammatory cytokines, for example, TNF- $\alpha$, IL-1, IL-6, IL-8, and NO as well as anti-inflammatory cytokines, and the level of expression of CD14 on monocytes is positively correlated with the grade of cellular activation. ${ }^{33-35}$

Here, we demonstrated a correlation between the postoperative monocyte CD14 expression and plasma levels of IL-6, IL-8, and NO. Production of cytokines like IL-6 and IL-8 as well as of NO is described as part of the inflammatory response to $\mathrm{CPB}{ }^{9,36,37}$ Moreover, coordinated production of IL-6 and IL-8 is often observed in various inflammatory conditions. ${ }^{38}$ During host defense and immunologic reactions, induction of inducible NO synthase occurs and large quantities of NO are produced by activated macrophages. ${ }^{8}$ Additionally, NO is generated by an endothelial nitric-oxide synthase. ${ }^{10,39}$ NO regulates vascular tone through a cyclic guanosine monophosphate (cGMP)-dependent signaling pathway. ${ }^{40}$ In addition, NO has cGMP-independent effects within the vasculature, such as inhibition of leukocyte adhesion, that relies on its ability to inactivate or antagonize superoxide. ${ }^{12,41}$ Our findings of increased CD14 expression in correlation with plasma concentrations of $\mathrm{NO}$ support a major role of monocytes during the early postop- erative time after CPB. Clinically, vasodilation and impaired myocardial contractility may be due to the effects of NO and IL- 6 and were followed by a prolonged need for inotropic medication. Increased vascular permeability may have contributed to a decrease of pulmonary oxygen exchange and the subsequent longer need for mechanical ventilation.

MPO is a specific marker of primary neutrophil granules and is only released in response to strong activating stimuli. MPO has both cytotoxic and antibacterial activities through its ability to interact with chloride and hydrogen peroxide to generate hydroxyl radical and hypochlorous acid. ${ }^{14}$ The high plasma levels of myeloperoxidase 2 hours after CPB indicate a profound activation of neutrophils in vivo during surgery. One of the most prominent proinflammatory cytokines for neutrophils is IL-8, which induces chemotaxis, granule release, and a respiratory burst. ${ }^{42}$ Following IL-8 stimulation, the IL-8 receptors are rapidly internalized and subsequently recycled to the plasma membrane or degraded. ${ }^{43,44}$ Down-regulation of IL-8 receptors therefore may be an indicator of in vivo exposure of the leukocyte to the corresponding agonist. Most interestingly, increased plasma levels of MPO were demonstrated together with increased levels of IL-8 and decreased expression of the IL-8 receptors CXCR2 on neutrophils. These findings indicate that neutrophils have been activated in vivo during $\mathrm{CPB}$. The fact that the expression of CXCR2 but not CXCR1 was down-regulated on neutrophils and monocytes suggests production of 1 or more of other proinflammatory chemokines of the IL-8 family with higher affinity for CXCR2 ${ }^{45,46}$ Recently, a selective nonpeptide CXCR2 antagonist has been shown to prevent IL-8-induced neutrophil chemotaxis in vitro and margination in vivo. ${ }^{47}$ 
Limitations of the study: Whereas the ratio of $\mathrm{PaO}_{2} / \mathrm{FIO}_{2}$ is well established to quantify disturbed lung function, documentation of compromised cardiovascular function is difficult. Measurement of cardiac output is, at least in theory, the gold standard but in most centers is not routine with pediatric cardiac surgery. Length of inotropic support was taken in this study as a surrogate of disturbed cardiovascular function. Concerning the method of $\mathrm{CPB}$, a number of factors like the use of aprotinin or the performance of ultrafiltration may influence the inflammatory response. However, in this study, CPB was done in a standardized manner in all patients, thus not accounting for the individual differences.

In conclusion, CPB in children induced several humoral and cellular variables of an acute systemic inflammatory response. The strong correlation of NO and MPO, presumably generated by activated neutrophils and monocytes with the extent of impairment of cardiovascular and respiratory function, reveals novel targets of therapeutic interventions. Because stimulation of neutrophils and monocytes may at least in part be dependent on CXCR2, antagonists of this receptor could offer a new therapeutic option.

We thank A. Urwyler (Institute of Immunology, University of Berne) for technical assistance.

\section{References}

1. Paparella D, Yau TM, Young E. Cardiopulmonary bypass induced inflammation: pathophysiology and treatment. An update. Eur J Cardiothorac Surg. 2002;21:232-4.

2. Hill GE. Cardiopulmonary bypass-induced inflammation: is it important? J Cardiothorac Vasc Anesth. 1998;12(Suppl 1):21-5.

3. Cremer J, Martin M, Redl H, et al. Systemic inflammatory response syndrome after cardiac operations. Ann Thorac Surg. 1996;61:171420.

4. Frering B, Philip I, Dehoux M, Rolland C, Langlois JM, Desmonts JM. Circulating cytokines in patients undergoing normothermic cardiopulmonary bypass. J Thorac Cardiovasc Surg. 1994;108:636-41.

5. Dehoux MS, Hernot S, Asehnoune K, et al. Cardiopulmonary bypass decreases cytokine production in lipopolysaccharide-stimulated whole blood cells: roles of interleukin-10 and the extracorporeal circuit. Crit Care Med. 2000;28:1721-7.

6. Frangogiannis NG, Mendoza LH, Lindsey ML, et al. IL-10 is induced in the reperfused myocardium and may modulate the reaction to injury. J Immunol. 2000;165:2798-808.

7. Tarnok A, Schneider P. Pediatric cardiac surgery with cardiopulmonary bypass: pathways contributing to transient systemic immune suppression. Shock. 2001;16(Suppl 1):24-32.

8. Moncada S, Higgs A. The L-arginine-nitric oxide pathway. $N$ Engl J Med. 1993;329:2002-12.

9. Hayashi Y, Sawa Y, Fukuyama N, Nakazawa H, Matsuda H. Inducible nitric oxide production is an adaptation to cardiopulmonary bypassinduced inflammatory response. Ann Thorac Surg. 2001;72:149-55.

10. Ruvolo G, Greco E, Speziale G, et al. Nitric oxide formation during cardiopulmonary bypass. Ann Thorac Surg. 1994;57:1055-7.

11. Finkel MS, Oddis CV, Jacob TD, Watkins SC, Hattler BG, Simmons RL. Negative inotropic effects of cytokines on the heart mediated by nitric oxide. Science. 1992;257:387-9.

12. Kubes P, Suzuki M, Granger DN. Nitric oxide: an endogenous modulator of leukocyte adhesion. Proc Natl Acad Sci U S A. 1991;88: 4651-5.

13. Niu X, Smith CW, Kubes P. Intercellular oxidative stress induced by nitric oxide synthesis inhibition increases endothelial cell adhesion to neutrophil. Circ Res. 1994;74:1133-40.

14. Weiss SJ. Tissue destruction by neutrophils. N Engl J Med. 1989;320: 365-76.

15. Delves PJ, Rosen FS. The immune system. $N$ Engl J Med. 2000;343: 37-49.

16. Luster AD. Chemokines-chemotactic cytokines that mediate inflammation. N Engl J Med. 1998;338:436-45.

17. Baggiolini M, Dewald B, Moser B. Interleukin-8 and related chemotactic cytokines-CXC and CC chemokines. Adv Immunol. 1994;55:97179.

18. Ivey CL, Williams FM, Collins PD, Jose PJ, Williams TJ. Neutrophil chemoattractants generated in 2 phases during reperfusion of ischemic myocardium in the rabbit. Evidence for a role for C5a and interleukin-8. J Clin Invest. 1995;95:2720-8.

19. Kukielka GL, Smith CW, LaRosa GJ, et al. Interleukin- 8 gene induction in the myocardium after ischemia and reperfusion in vivo. J Clin Invest. 1995;95:89-103.

20. Holmes WE, Lee J, Kuang WJ, Rice GC, Wood WI. Structure and functional expression of a human interleukin-8 receptor. Science. 1991;253:1278-80.

21. Murphy PM, Tiffany HL. Cloning of complementary DNA encoding a functional human interleukin-8 receptor. Science. 1991;253:1280-3.

22. Moser B, Barella L, Mattei S, et al. Expression of transcripts for two interleukin 8 receptors in human phagocytes, lymphocytes and melanoma cells. Biochem J. 1993;294:285-92.

23. Lequier LL, Nikaidoh H, Leonard SR, et al. Preoperative and postoperative endotoxemia in children with congenital heart disease. Chest. 2000;117:1706-12.

24. Khabar KS, elBarbary MA, Khouqeer F, Devol E, al-Gain S, al-Halees Z. Circulating endotoxin and cytokines after cardiopulmonary bypass: differential correlation with duration of bypass and systemic inflammatory response/multiple organ dysfunction syndromes. Clin Immunol Immunopathol. 1997;85:97-103.

25. Van Snick J. Interleukin-6: an overview. Апnи Rev Immunol. 1990;8: 253-78.

26. Plenz G, Song ZF, Reichenberg S, Tjan TD, Robeneck H, Deng MC. Left-ventricular expression of interleukin-6 messenger-RNA higher in idiopathic dilated than in ischemic cardiomyopathy. Thorac Cardiovasc Surg. 1998;46:213-6.

27. Burger A, Benicke M, Deten A, Zimmer HG. Catecholamines stimulate interleukin-6 synthesis in rat cardiac fibroblasts. Am J Physiol Heart Circ Physiol. 2001;281:H14-21.

28. Simmons DL, Tan S, Tenen DG, Nicholson-Weller A, Seed B. Monocyte antigen CD14 is a phospholipid anchored membrane protein. Blood. 1989;73:284-9.

29. Wright SD, Ramos RA, Tobias PS, Ulevitch RJ, Mathison JC. CD14, a receptor for complexes of lipopolysaccharide (LPS) and LPS binding protein. Science. 1990;249:1431-3.

30. Weidemann B, Brade H, Rietschel ET, et al. Soluble peptidoglycaninduced monokine production can be blocked by anti-CD14 monoclonal antibodies and by lipid A partial structures. Infect Immun. 1994; 62:4709-15.

31. Heidenreich S, Schmidt M, August C, Cullen P, Rademaekers A, Pauels HG. Regulation of human monocyte apoptosis by the CD14 molecule. J Immunol. 1997;159:3178-88.

32. Devitt A, Moffatt OD, Raykundalia C, Capra JD, Simmons DL, Gregory CD. Human CD14 mediates recognition and phagocytosis of apoptotic cells. Nature. 1998;392:505-9.

33. Schütt C. CD14. Int J Biochem Cell Biol. 1999;31:545-9.

34. Landmann R, Ludwig C, Obrist R, Obrecht JP. Effect of cytokines and lipopolysaccharide on CD14 antigen expression in human monocytes and macrophages. J Cell Biochem. 1991;47:317-29.

35. Marchant A, Duchow J, Delville JP, Goldman M. Lipopolysaccharide induces up-regulation of CD14 molecules on monocytes in human whole blood. Eur J Immunol. 1992;22:1663-5.

36. Butler J, Rocker GM, Westaby S. Inflammatory response to cardiopulmonary bypass. Ann Thorac Surg. 1994;58:1567-8.

37. Mathie RT, Ohri SK, Keogh BE, Williams J, Siney L, Griffith TM. Nitric oxide activity in patients undergoing cardiopulmonary bypass. J Thorac Cardiovasc Surg. 1996;112:1394-5. 
38. Kishimoto T, Akira S, Taga T. Interleukin-6 and its receptor: a paradigm for cytokines. Science. 1992;258:593-7.

39. Janssens SP, Shimouchi A, Quertermous T, Bloch DB, Bloch KD. Cloning and expression of a cDNA encoding human endotheliumderived relaxing factor/nitric oxide synthase. J Biol Chem. 1992;267: 14519-22.

40. Waldman SA, Murad F. Biochemical mechanisms underlying vascular smooth muscle relaxation: the guanylate cyclase-cyclic GMP system. J Cardiovasc Pharmacol. 1988;12(Suppl 5):S115-8.

41. Gaboury JP, Anderson DC, Kubes P. Molecular mechanisms involved in superoxide-induced leukocyte-endothelial cell interactions in vivo. Am J Physiol. 1994;266:H637-42.

42. Peveri P, Walz A, Dewald B, Baggioloni M. A novel neutrophilactivating factor produced by human mononuclear phagocytes. $J$ Exp Med. 1988;167:1547-59.

43. Samanta AK, Oppenheim JJ, Matsushima K. Interleukin-8 (monocyte- derived neutrophil chemotactic factor) dynamically regulates its own receptor expression on human neutrophils. J Biol Chem. 1990;265: 183-9.

44. Chuntharapai A, Kim KJ. Regulation of the expression of IL-8 receptor A/B by IL-8: possible functions of each receptor. J Immunol. 1995;155:2587-94.

45. Baggiolini M. Chemokines and leukocyte traffic. Nature. 1998;392: $565-8$.

46. Sabroe I, Timothy JW, Hebert CA, Collins PD. Chemoattractant cross-desensitization of the human neutrophil IL-8 receptor involves receptor internalization and differential receptor subtype regulation. J Immunol. 1997;158:1361-9.

47. White JR, Lee JM, Young PR, et al. Identification of a potent, selective non-peptide CXCR2 antagonist that inhibits interleukin-8 induced neutrophil migration. J Biol Chem. 1998;273:10095-8.

\begin{abstract}
Online-www.aats.org
Now you can get The Journal of Thoracic and Cardiovascular Surgery online. The Journal online brings you faster delivery time, easy searching of current and back issues, links to PubMed, AATS, WTSA, and other important sites, and more. Visit the Journal online today.
\end{abstract}

\title{
Receive tables of contents by e-mail
}

To receive the tables of contents by e-mail, sign up through our Web site at http://www.mosby.com/jtcvs

Choose E-mail Notification

Simply type your e-mail address in the box and click the Subscribe button.

Alternatively, you may send an e-mail message to majordomo@mosby.com.

Leave the subject line blank and type the following as the body of your message: subscribe jtcvs_toc

You will receive an e-mail to confirm that you have been added to the mailing

list.

Note that TOC e-mails will be sent out when a new issue is posted to the Web site. 